\title{
KEBIJAKAN PEMBINAAN USAHA KECIL DAN MENENGAH DI KOTAMADYA JAKARTA TIMUR
}

\author{
Agus Jamaludin \\ UniversitasIndraprasta \\ agus_jamaludin63@yahoo.co.id
}

\begin{abstract}
This research in Sub Cooperatives and SMEs in East Jakarta for 3 weeks. This study uses field reserch and library reserch. This study by exposing the facts existing at the sub-department of Cooperatives and SMEs municipality Jaktarta Timur. This paper uses one variable, descriptive data so it does not need to use statistical parameters, whose mother only explain the data. Usefulness to determine the policy of the local government in the East Jakarta Municipality development of SMEs in East Jakarta. The theory used most of by Law number 20 of 2008 concerning the business, micro, small and medium enterprises. Small businesses that are productive economic endeavors individual or business entity that is not a subsidiary or branch company. While medium-sized enterprises are productive economic enterprises stand-alone committed individual or business entity that is not a subsidiary or branch of a company that has a wealth of between $R p$ 500.000.000, - up to 10 millyar. The results of his research is that thanks to the policy in the development of SMEs in East Jakarta's SMEs grow and grow each year as a sign of revival of the economy. Policy development of SMES in East Jakarta Municipality has implemented them in apital strengthening, hold exhibitions, folk market, enhance the entrepreneurial spirit and others.
\end{abstract}

Keywords: Development of SMES 


\section{PENDAHULUAN}

Pembangunan nasional bertujuan untuk mewujudkan masyarakat adil dan makmur yang merata matrial dan spiritual berdasarkan Pancasila dan undang-Undang Dasar Republik Indonesia tahun 1945 dalam wadah Negara Kesatuan Republik Indonesia yang merdeka,bersatu dan berkedaulatan rakyat dalam suasana perikehidupan bangsa yang aman,tertib dan dinamis dalam lingkungan yang bersahabat dan damai.

Pembangunan nasional yang mencakup seluruh aspek kehidupan bangsa diselenggarakan bersama oleh masyarakat dan pemerintah.Masyarakat menjadi pelaku utama pembangunan dan pemerintah berkewajiban mengarahkan dan membimbing,melindungi serta menumbuhkan suasana iklim yang menunjang.

Tantangan berat yang dihadapi oleh bangsa Indonesia dewasa ini adalah tidak hanya menanggulangi krisis ekonomi saja,tetapi merubah paradigma dari ekonomi konglomerasi menjadi ekonomi kerakyatan serta meningkatkan daya saing KUKM (Koperasi Usaha Kecil dan Menengah) dalam mengahdapi pasar global.

Dalam rangka mengahadapi tantangan berat tersebut,maka perlu terus dikembangkan dan ditetapkan kebijakan dan program-program yang mengacu paradigma baru perekonomian Indonesia,yaitu kerakyatan sebagaimana telah ditetapkan dalam Tap MPR nomor
XVI/MPR/1998 tetang politik ekonomi.

Usaha mikro,kecil dan menengah merupakan kegiatan usaha yang mampu memperluas lapangan kerja dan memberikan pelayanan ekonomi secara luas kepada masyarakat,dan dapat berperan dalam proses pemerataan dan peningkatan kesejahteraan masyarakat.Mendorong pertumbuhan ekonomi dan berperan dalam mewujudkan stabilitas nasional.

Selain itu usaha Mikro, dan Menengah adalah salah satu pilar utama ekonomi nasional yang harus memperoleh kesempatan utama,dukungan,perlindungan dan pengembangan seluas-luasnya sebagai wujud keberpihakan yang tegas kepada kelompok usaha ekonomi rakyat,tanpa mengabaikan peranan usaha besar dan badan usaha Milik Negara.

Meskipun usaha Mikro,kecil dan menengah telah mewujudkan peranannya dalam perekonomian nasional,namun masih menghadapi berbagai hambatan dan kendala,baik yang bersifat internal maupun external dalam hak produksi dan pengolahan, pemasaran, sumber daya manusia,desain dan teknologi ,permodalan serta iklim usaha.

Upaya meningkatkan kesempatan,kemampuan dan perlindungan usaha mikro,kecil dan menengah telah ditetapkan berbagai kebijakan tentang pencadangan usaha, pendanaan dan pengembangannya namun belum optimal. Hal itu dikarenakan kebijakan tersebut belum dapat memberikan 
perlindungan, kepastian

berusaha,kepastian berusaha dan fasilitas yang memadai untuk pemberdayaan usaha Mikro,Kecil dan Menengah.

Untuk meningkatkan peran UKM dalam membangun kembali ekonomi kerakyatan tersebut,maka permasalahan klasik yang perlu segera dipecahkan yaitu rendahnya kualitas SDM UKM yang menimbulkan masalah-masalah seperti dibidang informasi, permodalan, pemanfaatan teknologi, pengembangan organisasi dan manajemen serta pemasaran.

Selain krisis ekonomi yang telah berlangsung lima tahun ini ketika banyak perusahaan menengah dan besar hancur bergelimpangan, justru sektor usaha kecil ini telah menunjukkan existensinya sebagai penyelamat ekonomi bangsa baik sebagai penampung tenaga kerja korban PHK perusahaan besar maupun menjadi devisa negara.

Pengusaha kecil dan menengah memiliki peran yang sangat srategis dalam perluasan kesempaaatan kerja dan berusaha,peningkatan ekspor dan pemerataan pendapatan,oleh sebab itu pemerintah terus berupaya untuk terus menerus mendorong, menumbuhkan dan memperkuat kemampuan usaha kecil agar mampu berkembang menjadi usaha menengah yang memiliki akar yangkuat dan kokoh sehingga mampu menjadi tulang punggungdalam menggerakkan roda ekonomi nasional. Peranan tersebut tentunya harus ditingkatkan dan didukung oleh pemerintah melalui berbagai pembinaan.

Berdasarkan masalah pada pendahu-luan tersebut, maka perumusan masalahnya yaitu: Bagaimana kebijakan pembinaan usaha kecil dan menengah di kotamdya Jakarta Timur?

Tujuan Penelitian

a. Untuk mengetahui bagaimana kebijakan pembinaan usaha kecil dan menengah di kotamadya Jakarta Timur.

b. Untuk mengetahui profil dan pengembangan serta pertumbuhan usaha kecil dan menengah.

\section{KAJIAN PUSTAK \\ Usaha Kecil Dan \\ Menengah(UKM)}

Berdasarkan Undang-Undang Republik Indonesia No 20 tahun 2008 tentang usaha Mikro, Kecil dan Menengah menerangkan tentang pengertian usaha Mikro, kecil dan menengah. Usaha Mikro adalah usaha produktip milik orang perorangan dan/badan usaha perorangan yang memenuhi kriteria usaha Mikro sebagaimana diatur dalam Undang-Undang.

Usaha kecil adalah usaha ekonomi produktip yang berdiri sendiri yang dilakukan oleh orang perorangan atau bukan cabang perusahaan yang dimiliki,dikuasai atau menjadi bagian baik langsung maupun tidak langsung dari usaha menengah atau usaha besar yang memenuhi kriteria usaha kecil 
sebagaimana dimaksud dalam Undang-Undang.

Usaha menengah adalah usaha ekonomi produktip yang berdiri sendiri yang dilakukan oleh orang perorangan atau badan usaha yang bukan merupakan anak perusahaan atau cabang perusahaan yang dimilki dikuasai atau menjadi bagian baik langsung maupun tidak langsung dengan usaha kecil atau usaha besar dengan jumlah kekayaan bersih atau usaha hasil penjualan tahunan sebagaimana diatur dalam UndangUndang.

Adapun kriteria usaha Mikro menurut UU adalah sebagai berikut:

1. Memiliki kekayaan bersih paling banyak Rp 50.000.000 (lima puluh juta rupiah). Tidak termasuk tanah dan bangunan tempat usaha.

2. Memiliki hasil penjualan tahunan paling banyak Rp 300.000 .000 (tiga ratus jutarupiah)

Kriteria usaha kecil menurut UU adalah sebagai berikut:

1. Memiliki kekayaan bersih lebih dari Rp 50.000.000,- (lima puluh juta rupiah) sampai dengan paling banyak Rp 500.000.000,(lima ratus juta rupiah) atau tidak termasuk tanah dan bangunan tempat usaha atau

2. Memiliki hasil penjualan tahunan lebih dari Rp 300.000.000,(tiga ratus juta rupiah sampai dengan paling banyak $\mathrm{Rp}$ 2.500.000.000,-(dua milyar lima ratus juta rupiah)

Adapun kriteria usaha menengah adalah sebagai berikut :
1. Memiliki kekayaan bersih lebih dari Rp 500.000.000,- (Lima ratus juta rupiah) samapai dengan paling banyak Rp 10.000.000.000,-(sepuluh milyar rupiah) tidak termasuk tanah dan bangunan tempat usaha atau,

2. Memiliki hasil penjualan tahunan lebih dari Rp 2.500.000.000 (dua milyar lima ratus juta rupiah ) sampai dengan paling banyak Rp 50.000.000.000,-(lima puluh milyar rupiah).

\section{Kebijakan Pemerintah terhadap UKM}

Usaha kecil dan menengah memiliki peran yang sangat strategis dalam perluasan kesempatan kerja dan berusaha,peningktan expor dan pemerataan pendpatan,oleh sebab itu maka pemerintah terus berupaya untuk terus mendorong,menumbuhkan dan memperkuat kemampuan usaha kecil agar mampu berkembang menjadi usaha yang besar yang memiliki akar yang kuat dan kokoh sehingga mampu menjadi tulang punggung dalam menggerakkan roda ekonomi nasional.

Peranan tersebut tentunya harus ditingkatkan dan didukung oleh pemerintah malalui barbagai pembinaan. Pemerintah dalam kebijakannya terhadap UKM dengan mengeluarkan payung hukum yaitu:

1. Pancasila yaitu keadilan sosial Bagi seluruh rakyat Indonesia.

2. UUD 1945 harus diwujudkan melalui pembangunan perekonomian nasional berdasarkan demokrasi ekonomi sesuai pasal 
5 ayat 1 , pasal 20 , pasl 27 ayat 2 dan pasal 33.

3. Ketetapan MPR RI nomor XVI/MPR RI/1998 tentang politik ekonomi dalam rangka demokrasi ekonomi,usaha mikro, usaha kecil dan menengah.

4. Undang-Undang nomor 9 tahun 1995 tentang usaha kecil.

5. Undang-Undang Republik Indonesia nomor 20 tahun 2008 tentang usaha mikro, kecil dan menengah.

6. SK Gubenur Propinsi DKI jakarta nomor 20 tahun 2002 tentang organisasi dan tata kerja koperasi,usaha mikro,kecil dan menengah Propinsi DKI jakarta.

Kebijakan pemerintah tersebut diatas dalam rangka pemberdayaan usaha mikro, kecil dan menengah perlu diselenggarakan secara menyeluruh,optimal dan berkesinambungan melalui pembinaan iklim yang kondusif,pemberian kesempatan berusaha,dukungan perlindungan dan pengembangan seluasluasnya,sehingga mampu meningkatkan kedudukan,peran,dan potensi usaha mikro,kecil dan menengah dalam mewujudkan pertumbuhan ekonomi,pemerataan dan peningkatan pendapatan rakyat,penciptaan lapangan kerja dan pengentasan kemiskinan.

\section{Pembinaan yang dilakukan oleh Pemda Kodya Jaktim terhadap UKM}

Pemberdayaan

mikro,kecil dan

diselenggara-kan

menyeluruh,

\author{
usaha \\ menengah \\ secara \\ dan
}

berkesinambungan melalui pengembangan iklim yang kondusif,pemberian kesempatan berusaha, dukungan,perlindungan dan pengembangan usaha yang seluas-kuasnya, sehingga mampu,meningkatkan

kedudukan,peran dan potensi usaha mikro,kecil dan menengah dalam mewujudkan pertumbuhan ekonomi,pemerataan dan peningkatan pendapatan rakyat,penciptaan lapangan kerja dan pengentasan kemiskinan.

Pemberdayaan adalah upaya yang dilakukan Pemerintah, Pemerintah Daerah, Dunia Usaha dan masyarakat secara sinergis dalam bentuk penumbuhan iklim dan pengembangan usaha terhadap usaha mikro,kecil dan menengah sehingga mampu tumbuh dan berkembang menjadi usaha yang tangguh dan mandiri.

Untuk memberdayakan usaha kecil dan menengah ini temtunya ditingkatkan dan didukung oleh pemerintah melalui berbagai pembinaan.Sebagaimana diuarai-kan dalam undang-undang nomor 20 tahun 2008 tentang usaha mikro,kecil dan menengah, maka pembinaan yang diberikan pemerintah difokuskan terhadap beberapa aspek yaitu sebagai berikut:

\section{a.Iklim usaha}

Pemerintah terus menerus berupaya untuk menciptakan iklim yang kondusif bagi terciptanya peluang berusaha seluas-luasnya bagi usaha kecil. 
Aspek-aspek menjadi perhatian pemerintah meliputi :

1. Pendanaan

Yang mencakup upaya-upaya memperbanyak jenis dan alokasi dana yang dapat dimanfaatkan usaha kecil,mengupayakan tata cara dalam memperoleh dana dan memberikan keringanan persyaraatan dalam pendanaan.

2. Persaingan Usaha

Mengatur kerja sama antara usaha kecil dan menengah dan besar agar dapat meningkatkan posisi tawar dalam melakukan transaksi,usaha dengan pihak lain,disamping itu untuk meningkatkan skala usahanya.

3. Prasarana

Pemerintah mengatur penyediaan prasarana memadai bagi pengembangan usaha kecil seperti transportasi,telekomunikasi,listrik,air bersih,lokasi usaha dan pasar.Diberlakukan perbedaan tarif berdasarkan ketetapan pemerintah bila secara langsung maupun tidak langsung.

4. Informasi

Pemerintah menetapkan peraturan pemerintah mengenai kebijakan pemanfaatan berbagai pusat bisnis dan sistim informasi bisnis yang dimiliki oleh pemerintah maupun swasta serta melakukan penyebaran informasi tersebut keseluruh wilayah tanah air.

5. Kemiitraan

Pemerintah menumbuhkan iklim usaha yang mendorong terjadinya kemitraan diantara pengu- saha kecil dengan pengusaha menengah dan besar.Disamping itu juga pemerintah harus mencegah terjadinya kerugian terhadap pengusaha kecil yang diakibatkan transaksi dengan pengusaha menengah dan besar.

6. Perizinan

Pemerintah menetapkan peraturan menetapkan peraturan dan kebijakan untuk menyederhanakan tata cara dan sistim perizinan yang dalam satu atap.

7. Perlindungan

Pemerintah membangun tempat usaha bagi pengusaha kecil atau usaha tradisional dan membangun sebagian lahan pada kawasan industri yang diperuntukan bagi pengusaha menengah dan besar.

\section{b.Pembinaan dan Pengembangan} Pemerintah memberikan pembinaan dan pengembangan bagi pengusaha kecil dan menengah melalui aspek-aspek:

1. Produksi

Memberikan pelatihan dan meningkatkan kemampuan pada aspek manajemen,tehnik produksi dan pengolahan termasuk di dalamnya memberikan kemudahan dalam pengadaan sarana dan prasarana produksi,pengolahan,bahan baku,bahan penolong dan pengemas.

2. Pemasaran

Pemasaran memberikan dukungan dalam pemasaran dengan menyediakan sarana dan serta dukungan promosi dan uji laba pasar,mengembangkan lembaga 
pemasaran dan jaringan distribusi.

3. Sumber Daya Manusia

Pemerintah menanamkan dan mengembangkan jiwa serta semangat kewirausahaan seperti: semangat kemandirian, berani mengambil resiko,tekun dan produktif.

4. Teknologi

Pengusaha kecil diberikan pelatihan untuk meningkatkan kemampuan dalam desain produk,pengendalian mutu dan alih teknologi.

\section{Permodalan Usaha Kecil dan Menengah}

Untuk meningkatkan kemampuan permodalan pengusaha kecil dan menengah pemerintah memberikan kredit perbankan, pinjaman dari lembaga keuangan bukan Bank, modal ventura, penyisihan laba BUMN dan sumbangan dari masyarakat termasuk sumbangan dana dari pengusaha besar.Pengsaha kecil dan menengah diberikan jaminan baik dari lembaga pinjaman swasta maupun lembaga pinjaman yang dimiliki oleh pemerintah.

Pengertian modal dan permodalan yaitu: modal adalah sejumlah dana atau uang atau nilai yang diprgunakan dalam membelanjakan semua keperluan usaha.Sedangkan permodalan adalah segala sesuatu yang dipergunakan atau diikutsertakan sebagai modal atau usaha.

Menurut UU RI nomor 20 tahun 2008 tentang usaha mikro,kecil pasal 22,dalam rangka meningkatkan sumber pembiyaan usaha,mikro,kecil dan menengah.Pemerintah melakukan upaya:

1. Pengembangan sumber pembiayaan dari kredit perbankan dan lembaga keuangan bukan Bank.

2. Pengembankan lembaga modal ventura

3. Pelembagaan terhadap transaksi anjak piutang.

4. Peningkatan kerjasama antara usaha mikro, dan usaha kecil melalui koperasi simpan pinjam dan koperasi jasa keuangan konvensional dan syariah.

5. Pengembangan sumber pembiayaan lain sesuai dengan ketentuan peraturan perundangundangan.

Untuk meningkatkan akses usaha mikro dan kecil terhadap sumber pembiyaan sebagaimana dimaksud dalam pasal 22. Pemerintah dan pemerintah daerah:

1. Menumbuhkan, mengembangkan dan memperluas jaringan lembaga keuangan bukan bank.

2. Menumbuhkan, mengembankan dan memperluas jangkauan lembaga pinjaman kre dit dan

3. Memberikan kemudahan dan fasilitas dalam memenuhi persyaratan untuk memperoleh pembiyaan.

Sedangkan untuk pembiyaan dan penjaminan usaha menengah menurut UU RI No 20 tahun 2008 pasal 24 yaitu:Pemerintah dan Pemerintah Daerah melakukan pemberdayaan usaha menengah 
dalam bidang pembiyaan dan penjaminan dengan:

1. Memfasilitasi dan mendorong peningkatan pembiyaan modal kerja dan investasi melalui pemasaran sumber dan pola pembiyaan, akses terhadap pasar modal dan lembaga pembiyaan lainnya.

2. Mengembangkan lembaga penjamin kredit dan meningkatkan fungsi penjamin expor.

Sedangkan menurut UU tentang usaha kecil nomor 9 tahun 1995 pasal 21 tentang pembiyaan dan penjaminan yaitu:

Sumber-sumber pembiyaan usaha kecil meliputi:

1. Kredit Perbankan

2. Penjamin lembaga keuangan bukan Bank

3. Pinjaman dari dana penyisihan sebagian laba BUMN

4. Hibah dan jenis pembiyaan lainnya.

Program Pemerintah propinsi

DKI Jakarta dalam rangka meningkatkan kemampuan permodalan usaha bagi pelaku ekonomi bagi golongan usaha skala kecil,koperasi dan penempatan tenaga kerja serta pengembangan wirau-saha baru di provinsi. Daerah Khusus ibukota Jakarta melalui surat Keputusan Gubenur nomor 38 tahun 2004 tanggal 29 Maret 2004.

Adapun bidang usaha yang dapat diberikan pinjaman modal usaha adalah golongan usaha kecil dan menengah yang melakukan kegiatan usaha di bidang:
a. Pertanian
b. Peternakan

c. Perikanan

d. Perindustrian

e. Perdagangan dan Jasa

Untuk

mendapatkan

pinjaman,golongan usaha kecil dan menengah harus mengajukan permohonan secara tertulis kepada pimpinan kantor cabang Pembantu PT Bank DKI setempat dengan menggunakan formulir yang disediakan.

Persyaratan untuk mengajukan permohonan pinjaman :

a. Untuk golongan skala kecil sektor formal :

1. 1 lembar fotocopy KTP DKI dan Kartu Keluarga atas nama pemohon

2. 1 lembar fotocopy Surat Izin Usaha

3. 1 lembar fotocopy surat jaminan

4. 2 lembar pas photo ukuran 4 $x 6$

5. Surat keterangan domisili, tempat tinggal dari lurah

6. Laporan keuangan berbentuk neraca rugi laba

7. Rekomondasi dari instansi pembina

8. Rekanan menggunakan dan pengembalian pinjaman.

b. Golongan usaha kecil sektor informal 1. 1 lembar fotocopy KTP DKI dan Kartu Keluarga atas nama para anggota dan ketua kelompok.

2. 2 lembar pas Photo ukuran $4 \times 6$

3. Rekomendasi dari instansi pembina

4. Surat keterangan domisisli dan tempat tinggal dari lurah 
5. Rencana pengembalian pinjaman.

\section{Promosi Produk-Produk UKM}

Promosi produk-produk UKM sesuai pasal 14 UU RI no 20 tahun 2008 yaitu:

a) Meningkatan promosi produk usaha, mikro,kecil dan menengah di dalam dan luar negeri

b) Memperluas sumber pendanaan untuk promosi produk-produk usaha mikro,kecil dan menengah di dalam dan luar negeri.

c) Memberikan insentif dan tatacara pemberian insentif untuk usaha mikro,kecil dan menengah yang mampu menyediakan pendanaan secara mandiri dalam kegiatan promosi produk di dalam dan di luar negeri.

d) Menfasilitasi pemilihan hak atas kekayaan intelektual atas produk dan desain usaha mikro,kecil dan menengah dalam kegiatan usaha dalam negeri dan expor.

\section{Pengembangan}

Sesuai dengan UURI no 20 tahun 2008 dalam pengembangan usaha kecil dan menengah sesuai pasal 16 yaitu:

Pemerintah dan pemerintah Daerah memfasilitasi pengembangan usaha dalam bidang:

a) Produksi dan Pengolahan

b) Pemasaran

c) Sumber Daya Manusia

d) Desain dan Teknologi .

a. Pengembangan dalam bidang produksi dan pengolahan dengan cara:
1. Meningkatkan tehnik produksi dan pengolahan serta kemam-puan manajemen usaha mikro,kecil dan menengah.

2. Memberikan kemudahan dalam pengadaan sarana dan prasarana,produksi dan pengolahan,bahan baku,bahan penolong dan kemasan bagi produksi usaha mikro,kecil dan menengah.

3. Mendorong penerapan atau standarisasi dalam proses produksi dan pengolahan.

4. Meningkatkan kemampuan rancang bangun dan perekayasaan bagi usaha menengah.

b. Pengembangan dalam bidang pemasaran.

1. Melaksanakan penelitian dan pengkajian pemasaran

2. Menyebar luaskan informasi pasar

3. Meningkatkan kemampuan manajemen dan tehnik pemasaran.

4. Menyediakan sarana dan prasarana yang meliputi penyelenggaraan uji coba pasar,lembaga pemasaran penyediaan rumah dagang dan promosi usaha mikro,kecil dan menengah.

5. Memberikan dukungan promosi produk,jaringan pemasaran dan distribusi.

6. Menyediakan tenaga konsultan propesional dalam bidang pemasaran.

c. Pengembangan dalam bidang sumber daya manusia dengan cara:

1. Memasyarakatan dan membudayakan kewirausahaan. 
2. Meningkatkan ketrampilan teknis dan manajerial.

3. Membentuk dan mengembangkan lembaga pendidikan dan pelatihan untuk melakukan pendidikan,pelatihan,penyuluhan,motivasi dan penciptaan wirausaha baru.

d. Pengembangan dalam bidang desain dan teknologi dengan cara:

1. Meningkatkan kemampuan dibidang desain dan teknologi serta pengendalian mutu.

2. Meningkatkan kerjasama dan alih teknologi.

3. Meningkatkan kemampuan usaha kecil dan menengah dibidang penelitian untuk mengembangkan desain dan teknologi baru.

4. Memberikan inisiatif kepada usaha mikro,kecil dan menengah yang mengembang-kan teknologi dan melestarikan lingkungan hidup.

5. Mendorong usaha mikro,kecil dan menengah untuk memperoleh sertifikat hak atas kekayaan intelektual.

\section{METODOLOGI PENELITIAN}

Tempat penelitian ini dilakukan di kantor SudinKoperasi dan UKM kotamadya Jakarta Timur selama 2 minggu.Karya ilmiah ini menggunakan 1 variabel, datanya des-kriptif sehingga tidak perlu menggunakan parameter statistik. Metode penelitian yang digunakan adalah:1. Penelitaian Kepustakaan (Library reserch),penelitian yang dilakukan dengan cara mengum- pulkan data dan mempelajari berbagai bukubuku,diktat,skripsi,tesis, dan lain sebagainya yang ada kaitannya dengan masalah yang diteliti, 2.Penelitian Lapangan(Field reserch)yaitu penelitian dengan pengamatan langsung pada obyek yang diteliti dengancara wawancara. Tehnik Analisa data yaitu mengekspos data yang ada dan mengamati di lapangan.

\section{HASIL PENELITIAN}

Usaha mikro,kecil dan menengah merupakan kegiatan usaha yang mampu memperluas lapangan kerja dan memberikan pelayanan ekonomi secara luas kepada masyarakat dan dapat berperan dalam proses pemerataan dan peningkatan pendapatan masyarakat,mendorong pertumbuhan ekonomi dan berperan dalam mewujudkan stabilitas nasional.Selain itu usaha mikro,kecil dan menengah adalah adalah salah satu pilar utama ekonomi nasional yang harus memperoleh kesempatan utama dukungan, perlindungan dan pengembangan seluas-luasnya sebagai wujud keberpihakan yang tegas kepada kelompok usaha ekonomi rakyat,tanpa mengabaikan peranan usaha besar dan badan usaha milik negara.

Untuk meningkatkan kesempatan,kemampuan dan perlindungan usaha mikro,kecil dan menengah telah ditetapkan berbagai kebijakan tentang percadangan usaha pendanaan dan pengem- 
bangannya namun belum optimal.Hal itu dikarenakan kebijakan tersebut belum dapat memberikan perlindungan, kepastian berusaha,dan fasilitas yang memadai untuk memberdayakan usaha mikro,kecil,dan menengah.

Sehubungan dengan itu usaha mikro,kecil dan menengah perlu diberdayakan dengan cara:

1. Penumbuhan iklim usaha yang mendukung pengembangan usaha mikro,kecil dan menengah.

2. Pengembangan dan pembinaan usaha mikro,kecil dan menengah.

Keberadaan sektor usaha kecil dan menengah sudah mendapat perhatian penuh dari semua pihak mengingat banyaknya manfaat dan kelebihan yang dimilki sektor kecil dan menengah antara lain:

a) Perusahaan kecil dan menengah dapat menyediakan lapangan kerja

b) Perusahaan kecil ikut memberikan kontribusi dalam membayar pajak.

c) Merupakan ujung tombak industri nasional.

d) Memproduksi banyak sektor kebutuhan pokok rakyat.

e) Merupakan pedagang perantara dan pengumpul hasil panen.

f) Tersebar diseluruh wilayah Negara Indonesia.

Adapun data UKM di wilayah Kota Jakarta Timur adalah seperti terlihat pada tabel di bawah ini.

Tabel 1

Data UKM Di Wilayah Kota Administrasi Jakarta Timur

\begin{tabular}{|c|c|c|c|c|}
\hline \multirow{2}{*}{ No } & \multirow{2}{*}{ KECAMATAN } & \multicolumn{2}{|c|}{ USAHA } & \multirow{2}{*}{ JUMLAH UKM } \\
\hline & & KECIL & MENENGAH & \\
\hline 1 & Matraman & 14.712 & 2.341 & 17.053 \\
\hline 2 & Jatinegara & 25.182 & 3.834 & 29.016 \\
\hline 3 & Pulogadung & 20.151 & 3.807 & 23.958 \\
\hline 4 & Kramat Jati & 21.985 & 4.563 & 26.548 \\
\hline 5 & Pasar Rebo & 11.105 & 3.347 & 14.452 \\
\hline 6 & Cakung & 18.118 & 2.508 & 20.626 \\
\hline 7 & Duren Sawit & 14.510 & 3.614 & 18.124 \\
\hline 8 & Makasar & 8.295 & 2.107 & 10.402 \\
\hline 9 & Ciracas & 7.050 & 3.264 & 10.314 \\
\hline
\end{tabular}




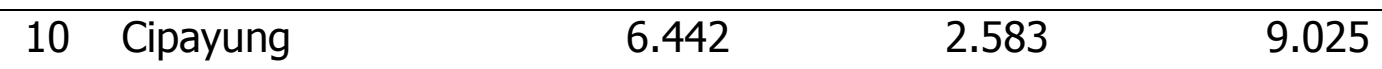

$\begin{array}{llll}\text { JUMLAH } & 147.550 & 29.627 & 162.465\end{array}$

Sumber: Sudin Koperasi dan UKM

Tabel 2

Data Perkembangan Usaha Kecil Di Wilayah Kodya Jakarta Timur Data Usaha Kecil

Kelompok Usaha Kecil

1. Usaha Perdagangan

2. Usaha Industri non pertanian

3. Usaha pertanian

4. Usaha jasa

Total 48.000

1.600

9.340

147.440

Jumlah usaha kecil tersebar di 10 kecamatan

1. Kecamatan Jatinegara

25.170

2. Kecamatan Matrama

14.700

3. Kecamatan Pulogadung

20.140

4. Kecamatan Cakung

18.105

5. Kecamatan Duren Sawit

14.500

6. Kecaamatan Kramat Jati

21.975

7. Kecamatan Pasar Rebo

11.095

8. Kecamatan Cipayung

6.430

9. Kecamatan Ciracas

7.040

10. Kecamatan Makasar

8.285 
3.Data potensi produk unggulan usaha kecil di 10 kecamatan

1. Kecamatan Jatinegara Aneka Boneka, Handicraft

2. Kecamatan Matraman Konveksi, Asesoris

3. Kecamatan Pulogadung Mebel Kayu, konveksi, Bordir

4. Kecamatan Cakung Konveksi, Handicraff, sepatu, Tas.

5. Kecamatan Durensawit Mebel, Handycraft

6. Kecamatan Kramat Jati Handicraft, Akar wangi, Asesoris.

7. Kecamatan Pasar Rebo Aneka boneka,kaligrafi, Dodol, jenang, handicraft

8. Kecamatan Cipayung Pot fiber,kasur,konveksi

9. Kecamatan Ciracas Konveksi,busana

muslim,Tropi,handicraft

10. Kecamatan Makasar Handicraft,tas.

Upaya yang telah dilaksanakan oleh Pemkot Jakarta Timur yaitu:

1. Memfasilitasi kredit usaha kecil dan menengah ke Perbankan maupun pihak BUMN.

2. Mengadakan pameran dan gelar pasar rakyat produk usaha kecil dan menengah.

3. Mengadakan peningkatan keterampilan dibidang manajemen usaha, teknologi.

4. Mengadakan penilaian kinerja usaha kecil dan menengah dalam rangka memotivasi usaha kecil dan menengah.
5. Menginventarisir data UKM sebagai bahan evaluasi pengembangan UKM.

6. Melaksanakan bimbingan tehnis terhadap sentra usaha kecil dan menengah.

Pembinaan yang telah dilakukan oleh Sudin Koperasi danUKM:

1. Memfasilitasi kredit UKM

2. Mengadakan pameran dalam daerah dan luar daerah.

3. Peningkatan manajemen UKM

4. Pengadaan penilaian kinerja UKM

5. Pasar Rakyat.

KESIMPULAN 
1. Usaha kecil dan menengah telah teruji dari gelombang krisis ekonomi di Indonesia dan selalu eksis mengemban pertumbuhan ekonomi.

2. Usaha kecil dan menengah dapat menampung tenaga kerja dari korban PHK dan menumbuh kembangkan jiwa kewiraswastaan bagi masyarakat.

3. Usaha kecil dan menengah mampu memenuhi kebutuhan masyarakat dan dapat memberdayakan masyarakat dalam mengembangkan ekonomi kerakyatan.

4. Usaha kecil dan menengah bersikap jujur dan patuh membayar pajak dan membantu pemerintah di sektor ekonomi masyaarakat.

\section{Saran}

1. Kebijakan pemerintah pusat maupun daerah harus ditingkatkan lagi pembinaannya terhadap UKM agar tumbuh dan berkembang UKM tersebut.
2. Pembinaan UKM di sektor permodalan, pemasaran,produksi,teknologi dan manjemen haruas ditingkatkan oleh Sudin Koperasi dan UKM Pemkot Jaktim.

3. Bagi masyarakat UKM harus lebih tangguh, disiplin, inovatif dalam mengembangkan UKM- nya

\section{DAFTAR PUSTAKA}
Undang-Undang Republik Indonesia nomor 20 tahun 2008 tentang usaha mikro,kecil dan menengah.
Kementerian UMKM dan Koperasi,Rencana Strategis 2009- 2014.
Kementerian UMKM dan Koperasi,Rencana Kerja Pemerintah tahun 2014 bidang Pemberdayaan UMKM dan Koperasi.
UU No 9 tahun 1995 tentang Usaha Kecil

